\title{
The Development of Innovative Learning Material with Integration of Project and Multimedia for the Teaching of Gravimetry
}

\author{
Debby SuciMartalina \\ Department of Chemistry Education, Graduate Study \\ Program (Program Pascasarjana), \\ Universitas Negeri Medan \\ Medan, North Sumatera, INDONESIA, 20221, E-mail: \\ debbysuci@gmail.com
}

\author{
ManiharSitumorang \\ Department of Chemistry, Faculty of Mathematics and \\ Natural Sciences (FMIPA), \\ Universitas Negeri Medan, Medan, North Sumatera, \\ INDONESIA, 20221 \\ Corresponding authors: E-mail: msitumorang@unimed.ac.id
}

\author{
AjatSudrajat \\ ${ }^{2}$ Department of Chemistry Education, Graduate Study Program (Program Pascasarjana), \\ Universitas Negeri Medan, \\ Medan, North Sumatera, INDONESIA, 20221
}

\begin{abstract}
Implementation of Indonesian National Qualifications Framework (Kerangka Kualifikasi Nasional Indonesia, KKNI)as the basis of competence standardin UniversitasNegeri Medanhas brought the change in the teaching and learning activities. Innovation of chemistry learning material is needed to provide the students with appropriate resources to improve their knowledge and analytical skills. The study is aimed to development innovative of learning material with integration of project and multimedia for the teaching of Gravimetry topic of Analytical Chemistry. The research is carried out in the Department of Chemistry, Faculty of Mathematics and Natural Sciences, UniversitasNegeri Medan in three stages: (1) the development and standardization of a set of innovative learning material, (2) the preparation of project with multimedia in accordance with the KKNI curriculum, and (3) implementation of the developed learning material to support teaching and learning activities. The results showed that package of standard innovative learning material has been developed for Gravimetry topic. The contents of chemistry subject have been enriched with contextual examples with integration of projects to meet the requires learning material for undergraduate student. The learning package has been designed in a systematic order to be able to motivate the students to learn chemistry. The learning facilities of multimedia was provided in the developed learning material which are found to be adequate to support the students to learn Analytical chemistry independently. It has been known that the students' knowledge and skill are improved by the implementation of the chemistry projects.
\end{abstract}

Keywords-Innovative learning material, Multimedia, Chemistry project, Gravimetric analysis

\section{INTRODUCTION}

The need for an innovative learning materialisurgently required in the digital era as it is known that the students are tend to do their learning study in line with current technology. An innovative learning material is proposed to improve the quality of education throughmaximizing the teaching and learning activity to achieve the target learning competence. An innovative learning material can be used to facilitate the learners moving from conventional learning style into student-centered learning[1].It is expected that the learning materials be able to help the students to understand the concept of the subject they learn and resulting in achieving thetarget learning competencies[2,3]. Furthermore, an innovative learning material can be used as a productive resources that can motivated the learner to study[4,5].

Various strategies have been conducted in the teaching and learning activities to support competence curriculum in the university as required by the Indonesian National Qualification Framework (KKNI) [6].The KKNI is a competency qualification level that can compare, equalize, and integrate the education and job training in accordance with the work structure in various sectors. Based on the learning outcomes in KKNI, students areideally expected to be more active, mastering the material, having the ability to work, able to solve problems in the lecture 
process, and producingacademic products. Therefore, innovative learning materials are needed in accordance with the curriculum so that they can help the students to achieve the desire competencies[7].The use of multimedia in teaching and learning materials is very interesting since it can integrate various learning facilities in to a text that can motivate the students to learn independently[8,9]. Multimedia has wide functions that allow it to place a large amount of information, search and quick access to the information needed, the delivery of knowledge that is unbiased and appropriate to students, the visual percentage of many complex phenomena and processes, the use of graphic design, and information acquisition. [10] Multimedia applications provide teachers with an excellent opportunity to demonstrate and visualize learning material in a more clear and easy way to understand, as well as allowing teachers to prepare learning material for students to optimize their study habits[11,12].

The development of innovative learning materials by integrating project and combined with multimedia is assigned to be a good strategy to be applied in the teaching of chemistry. The students can master themselves in various skills and knowledge though the project such as creativity in thinking, solving problems, and interacting and assisting in investigations that lead to the resolution of real problems[13,14].Furthermore, these approaches affect academic achievement, long-lasting learning, and positive learning functions. Project-based learning considers the project not as an objective but as a means of suppressing aspects of the learning process rather than product aspects that can improve students' knowledge and skills $[15,16]$.

Gravimetric analysis is one of the quantitative methods in Analytical Chemistry that has been usedto determine a compound through the formation of deposit and weighing of the compounds which are analyzed[17,18]. The gravimetrictechnique is very important for science students as it covers the knowledge and skills inanalytical method [19].Gravimetric analysis is one of the difficult topics because it need to combine the concepts theories with the technical skills in the laboratory and to complete the existing calculations in finding the target yield in the analytical determination. The topic in gravimetricanalysis are consisted of the sample preparation, choosing of selective precipitation reagents, the strategy to proceedprecipitate formation, the techniqueson separation, digestion, purification, drying and ignition, and the calculation of the yield[20-22]. Those techniques are compulsory for undergraduate chemistry students in the analytical assay. Therefore, the students need to have innovative teaching material in accordance with a curriculum that summarizes all gravimetric topicsin a systematicorder to make it easy to understand andfinally improve their learning outcomes. The research was aims to provide an innovative chemistry learning material with integration of project and multimedia in the teaching of Gravimetric analysis topic to be implemented to improve students' knowledge and skill.

\section{RESEARCH METHOD}

\section{A. Research Procedures}

The study is designed to develop an innovative learning materials with integration of projects and multimedia onto theGravimetric analysis topic, followed the procedures explained previously[23,24].The work was carried out in the Department of Chemistry, Faculty of Mathematics and Natural Sciences,UniversitasNegeri Medan, in three stages: (1) the development and standardization of a set of learning material, (2) the preparation of project with multimedia in accordance with the KKNI curriculum, and (3) the implementation of the learning material to support teaching and learning activities. The learning material was evaluated by using standard assessment sheets to meet the book criteriarequired by the National Education Standards Agency of Indonesia (BSNP). Students' skills through conducting the project were measured by using assessment sheets of project skills. Astandard questionnairewas used to investigate students' motivation in learning chemistry when they are using the developed innovative learning materials. Student'soutcomes are obtained from the mark of submitted project reports in combination with students' achievement from the ability to answer the questions in a set of objective test.

\section{B. Development and Standardization of Innovative Learning Materials}

The development of an innovative learning material was carried out by enriching the Gravimetry analysis topic with contextual example followed by integration of relevant project and multimedia[25].The projects are designed to be completed in a two to three hours laboratory work. Multimedia are integrated in the learning material to bring the chemistry theory into practice to be used as pre-working instruction to commence the selected project. The chemistry learning package was validated by experts and its feasibility was assessed by using standard questionnaire to meet BSNP book criteria. The learning material was then provided both as hard copy (print) and e-book (in a $\mathrm{CD}$ ) to be used as a learning media in the teaching of Gravimetry analysis.

\section{Implementation of Innovative Learning Material}

Gravimetry analysis was taught based on the schedule time table in the Department. An allocated timetable was prepared for objective test to cover both experimental and control class. The trial was conducted on two groups with different treatments. The developed learning material was used as a main learning resource for experimental group and ordinary textbook with separate instruction was prepared for control class. Before the treatment, each group was given a pretest. All students areasked 
to study hard and submitted their tasks on time. The students in experimental group was asked to study the material of Gravimetric analysis and work on the existing projects that are provided in the innovative learning materials while the control group was asked to study the chemistry handbook on the gravimetric analysis material with supplementation of ordinary laboratory work. Student's skills are assessed during their study time when doing the project or laboratory works. Students' skills in experimental class wereassessed from project works by using project skill observation sheets. Posttest was provided at the end of the study program in both groups. The students were then asked for their motivationsto study Gravimetry analysis.

\section{RESULT AND DISCUSSION}

\section{A. The Development of Learning Material}

The development of the learning materials has been carried out through enrichment of the chemistry contents with contextual examples into Gravimetric topic followed by integration of relevant projects and multimedia[26,27].The learning material consisted of ten sub-topics, namely: (1) Deposition Mechanism, (2) Crystal Purification, (3) Formation of Sediment, (4) Reducing Impurity, (5) Separation and Bleaching of Sediment, (6) Drying the Sediment, (7) Calculating the Yield Results, (8) Precipitating Compounds, (9) Special Gravimetric Analysis Techniques, (10) Gravimetric Application. The description of innovation is summarized in Table I. There are three projects are integrated in the book that covers the subject being taught. The description towards projects which were integrated into the innovative learning material is displayed in Table II. Other components that are integrated in to learning material are video and multimedia software in the form of flipbook maker.

TABLE 1. The Description Of Innovation Which Is Integrated And Developed To The Learning Materials

\begin{tabular}{|c|c|}
\hline Topics & Description \\
\hline Deposition Mechanism & $\begin{array}{l}\text { The development and innovation of learning materials in the sedimentation mechanism is enriched with the sub-subject matter of } \\
\text { nucleation, crystal growth, and crystal formation. }\end{array}$ \\
\hline Crystal Purification & $\begin{array}{l}\text { Development and innovation of crystal purification teaching materials enriched with the discussion of copresipitation, inclusion, and } \\
\text { occlusion. }\end{array}$ \\
\hline Formation of Sediment & $\begin{array}{l}\text { The development and innovation of sediment formation teaching materials is enriched with sub-topics of sediment types, sediment } \\
\text { growth due to nucleation, and colloid deposition. }\end{array}$ \\
\hline Reducing Impurity & $\begin{array}{l}\text { The development and innovation of teaching materials to reduce sediment is integrated with the video of crystal purification } \\
\text { (recrystallization). Material is arranged in e-book form. }\end{array}$ \\
\hline $\begin{array}{l}\text { Separation and Bleaching of } \\
\text { Sediment }\end{array}$ & $\begin{array}{l}\text { The development and innovation of separation and sediment washing materials. In the sub-subject of sediment separation material is } \\
\text { equipped with images of the tools used to separate sediment and integrated with video }\end{array}$ \\
\hline Drying the Sediment & $\begin{array}{l}\text { The development and innovation of teaching materials to dry the sediment is equipped with images of thermographic instruments and } \\
\text { thermographic curves. }\end{array}$ \\
\hline $\begin{array}{l}\text { Calculating the Yield } \\
\text { Results of Sediment }\end{array}$ & $\begin{array}{l}\text { The development and innovation of learning materials to calculate the results of the yield of the sediments, enriched with examples of } \\
\text { calculating the results of sediments and practice questions. }\end{array}$ \\
\hline Precipitating Compounds & $\begin{array}{l}\text { The development and innovation of precipitating compound teaching materials is enriched with the sub-subject matter of inorganic } \\
\text { precipitating compounds and organic precipitating compounds which are equipped with examples of precipitating compounds and their } \\
\text { deposited elements. }\end{array}$ \\
\hline $\begin{array}{l}\text { Special Gravimetric } \\
\text { Analysis Techniques }\end{array}$ & $\begin{array}{l}\text { The development and innovation of teaching materials for special gravimetric analysis techniques is enriched with homogeneous sub- } \\
\text { topic, direct evaporation and indirect evaporation. }\end{array}$ \\
\hline Gravimetric Application & $\begin{array}{l}\text { The development and innovation of gravimetric application teaching materials is enriched with sub staples of sulfur determination } \\
\text { material, chloride determination, iron determination, nickel determination, and determination of carbon and hydrogen. }\end{array}$ \\
\hline
\end{tabular}


TABLE II. The Description Of Projects Which Are Integrated To The Innovative Learning Materials

\begin{tabular}{|c|c|c|}
\hline Project Title & Competences & Description \\
\hline $\begin{array}{l}\text { The determination of } \\
\text { calcium content in } \\
\text { eggshell }\end{array}$ & $\begin{array}{l}\text { Determining calciumlevels in } \\
\text { eggshellsgravimetricallythrough } \\
\text { laboratory experiments and } \\
\text { gravimetric calculations. }\end{array}$ & $\begin{array}{l}\text { Students will search for some references related to gravimetric determination of calcium levels. In this } \\
\text { section, students will issue projects (tools, materials and work procedures). Determining the results of } \\
\text { the sample filter, the weight of the filter paper and the weight of the sediment and complexes that } \\
\text { occur in each experiment. Students make a table based on experimental results data, make reactions } \\
\text { that occur during the experiment, calculate the percentage level in the sample, connect with the theory } \\
\text { that supports the project, analyze the performance and the factors that cause it, and make conclusions }\end{array}$ \\
\hline $\begin{array}{l}\text { The determination of } \\
\text { chloride content in sea } \\
\text { water }\end{array}$ & $\begin{array}{l}\text { Determining of chloride content } \\
\text { in sea water } \\
\text { Gravimetricallythrough } \\
\text { laboratory experiments and } \\
\text { gravimetric calculations }\end{array}$ & $\begin{array}{l}\text { Students will search for some references related to gravimetric determination of chloride levels. In this } \\
\text { section, students will design projects (tools, materials and work procedures). Student determine the } \\
\text { results of the measurement of the sample weight, the weight of the filter paper and the weight of the } \\
\text { sediment and observed the changes that occurred in each experiment. Students make observation tables } \\
\text { based on experimental results data, make reactions that occur during the experiment, calculate the } \\
\text { percentage of calcium levels in the sample, connect the results of experiments with theories that } \\
\text { support the project, analyze the success or failure of the project and the factors that cause it, and make } \\
\text { conclusions. }\end{array}$ \\
\hline $\begin{array}{l}\text { The determination of } \\
\text { sulphur content in } \\
\text { fertilizer }\end{array}$ & $\begin{array}{l}\text { Determining of sulphur content } \\
\text { in fertilizer } \\
\text { gravimetricallythrough } \\
\text { laboratory experiments and } \\
\text { gravimetric calculations }\end{array}$ & $\begin{array}{l}\text { Students will search for some references related to gravimetric determination of sulphur levels. In this } \\
\text { section, students will design projects (tools, materials and work procedures). Student determined the } \\
\text { results of the measurement of the sample weight, the weight of the filter paper and the weight of the } \\
\text { sediment and observed the changes that occurred in each experiment. Students make observation tables } \\
\text { based on experimental data, make reactions that occur during the experiment, calculate the percentage } \\
\text { of sulfate levels in the sample, connect the results of experiments with theories that support the project, } \\
\text { analyze the success or failure of the project and the factors that cause it, and make conclusions. }\end{array}$ \\
\hline
\end{tabular}

\section{B. Standardization of Learning Material}

Standardization of learning material has been conducted and the results are summarized in Table III. The learning material has met the required criteria given by the BSNP where the learning material was assigned to be very good (average 3.65). Both the lectures (average 3.72) and senior students (average 3.59) gave positive response to the feasibility of a developed learning package. This means that the chemistry contents and the projects integrated in the chemistry text of an innovative learning material are suitable for teaching of gravimetric analysis for undergraduate chemistry and other majoring science students.

TABLE III. Respondents Opinion To The Feasibility Of An Innovative Learning Material

\begin{tabular}{|l|c|c|c|}
\hline \multirow{2}{*}{$\begin{array}{l}\text { Elements of } \\
\text { assessment }\end{array}$} & \multicolumn{2}{|c|}{ Respondents Respond } & \multirow{2}{*}{ Average } \\
\cline { 2 - 3 } & Student $(\boldsymbol{n}=\mathbf{1 4})$ & $\begin{array}{c}\text { Lecturer } \\
(\boldsymbol{n}=\mathbf{3})\end{array}$ & \\
\hline Content & 3.59 & 3.75 & 3.67 \\
\hline Language & 3.49 & 3.67 & 3.58 \\
\hline Presentation & 3.66 & 3.74 & 3.70 \\
\hline Graphic & 3.63 & 3.73 & 3.68 \\
\hline Average & $\mathbf{3 . 5 9}$ & $\mathbf{3 . 7 2}$ & $\mathbf{3 . 6 5}$ \\
\hline
\end{tabular}

\section{Implementation of Innovative Learning Material}

The developed learning material has been implemented as a learning media in the class on the teaching of Gravimetry analysis. The students in experimental class are prepared the learning material containing the projects to be completed in a scheduled time. The students are assessed based on their performance skills in handling the project, project reports, and from their performance on academic achievement (obtained from posttest). In completing the project, each student took different tasks according to the needs so that the project could run smoothly. In each group, there were students who were tasked with preparing tools and materials, carrying laboratory works, recording project results, and washing up laboratory glassware.The reports were provided individually from data project results. Skill assessment was recordedindividually during their project works. Students performance in psychomotor was assessed in three aspects as summarized in Table IV. 
TABLE IV. The Result Of Psychomotor Skill Of Students

\begin{tabular}{|c|c|c|}
\hline \multicolumn{2}{|r|}{ Performance Criteria } & Average \\
\hline \multirow{2}{*}{ Pre work } & - Clothes & 2.5 \\
\hline & - Readiness for project & 2.5 \\
\hline \multirow{5}{*}{ Project } & - Project planning preparation & 2.6 \\
\hline & - Scheduling & 2.7 \\
\hline & - Project completion and monitoring & 2.7 \\
\hline & - Preparation of reports and presentations & 2.7 \\
\hline & - Evaluation & 2.5 \\
\hline \multirow{7}{*}{ Experiment } & - Work systematics & 2.6 \\
\hline & - Skill & 2.5 \\
\hline & $\begin{array}{l}\text { - Use of tools and materials in the } \\
\text { experiment }\end{array}$ & 2.7 \\
\hline & - Management of residual experiments & 3.0 \\
\hline & - Work result & 2.9 \\
\hline & - Cleanliness & 2.8 \\
\hline & - Experiment result report & 2.9 \\
\hline \multicolumn{2}{|r|}{ Average } & 2.7 \\
\hline
\end{tabular}

It was revealed that the students in experimental class have achieve the required skills in handling laboratory work in thegiven projects (average score 2.7). The learning materials which are integrated with videos on Gravimetric analysis has to be red before commencing the projects in order the students know what they have to do in their projects, and the work can be completed on time in an efficient manner [28,29]. The measurement of student learning motivation was conducted by asking students opinionson the use of learning package to study Gravimetry. Students' motivation was presented in Table V. The results of student learning motivation using innovative teaching materials that have been developed are considered to be very high (average of 4.35).

TABLE V. The Result Of Student Motivation Towards Innovative Learning Material

\begin{tabular}{|c|l|c|}
\hline No & \multicolumn{1}{|c|}{ Indicator } & Average Score \\
\hline 1 & Challenge & 4.20 \\
\hline 2 & Curiosity & 4.25 \\
\hline 3 & Engagement & 4.36 \\
\hline 4 & Confidence & 4.37 \\
\hline 5 & Attention & 4.29 \\
\hline 6 & Relevance & 4.36 \\
\hline 7 & Satisfaction & 4.64 \\
\hline \multicolumn{2}{|c|}{ Average } & $\mathbf{4 . 3 5}$ \\
\hline
\end{tabular}

At the end of the study, the posttest has been given to both groups, and student learning outcomes are summarized in Table VI. Based on the results of the analysis using the KolmogorovSmirnov test, the overall data obtained in both the experimental and control classes are normally distributed. The results showed that the students in experimental class obtained higher thatin control class (see Table VI). It could be stated that the difference of increasing learning outcomes between the experimental class and the control class was caused by the use of learning materials that integrated with projects and multimedia. The developed learning media are found to be effective to motivate students to learn chemistry independently. Their enthusiasm, interest, and involvement in learning chemistry are improved. The students are using learning package to get answers to their problem interests, and keep the students to stay focused on the subject they learn.

TABLE VI. The Analysis Of Students Learning Outcomes

\begin{tabular}{|c|c|c|c|c|}
\hline \multirow{2}{*}{ Class } & \multicolumn{4}{|c|}{ Evaluation test } \\
\cline { 2 - 5 } & \multicolumn{2}{|c|}{ Pre Test } & \multicolumn{2}{c|}{ Post Test } \\
\cline { 2 - 5 } & $\begin{array}{c}\text { Average } \\
\text { Score }\end{array}$ & $\begin{array}{c}\text { Normality } \\
\text { (Sig.) }\end{array}$ & Average Score & $\begin{array}{c}\text { Normality } \\
\text { (Sig.) }\end{array}$ \\
\hline $\begin{array}{c}\text { Experime } \\
\text { nt }\end{array}$ & $31.07 \pm 5.94$ & 0.366 & $83.21 \pm 8.46$ & 0.510 \\
\hline Control & $31.43 \pm 7.18$ & 0.804 & $75.71 \pm 6.75$ & 0.450 \\
\hline
\end{tabular}

With the existence of innovative learning materials using projects and multimedia in learning gravimetric analysis, students can use independent learning time more effectively. The desire of students to study chemistry using innovative teaching materials and integrated projects and multimedia contributes to improving student learning outcomes that occur in the shift of teacher-centered learning (student teaching learning) to studentcentered learning

\section{CONCLUSION}

The innovative learning material with integration of project and multimedia for the teaching of Gravimetryanalysis suited to the KKNI curriculum has been developed. The development process is proven to be successful as it is valid and very feasible to be used for the teaching process of gravimetric analysis. Implementation of the learning package revealed to be effective to improve several aspects for the students such as motivation, psychomotor skills and learning outcomes. It is recommended to applly the innovation to another chemistry topic for having better results in students outcome. 


\section{ACKNOWLEDGEMENTS}

Authors would like to acknowledge Analytical Chemistry lecturers of Department of Chemistry in Universitas Negeri Medan for their help in the study. This work was supported by Directorate Research and Community Service, Directorate General Strengthen Research and Development, Ministry of Research, Technology and Higher Education of the Republic of Indonesia, Under Tim Pascasarjana, No. 073/SP2H/LT/DRPM/2018.

\section{REFERENCES}

[1]. M. Situmorang, M. Sitorus, W. Hutabarat, Z. Situmorang, "The Development of Innovative Chemistry Learning Material for Bilingual Senior High School Students in Indonesia", International Educational Studies.8(10), pp. 72-85, 2015.

[2]. J. D. Herron, "The Chemistry Classroom: Formulas for Succesful Teaching", American Chemical Society. WashingtonDC, 1996.

[3]. M. Situmorang, "Pengembangan Buku Ajar Kimia SMA Melalui Inovasi Pembelajaran dan Integrasi Pendidikan Karakter untuk Meningkatkan Hasil Belajar Siswa", Prosiding Semirata FMIPA, Universitas Lampung. pp. 237-246, 2013.

[4]. J R. Silaban, B. Septiani, W. Hutabarat, "Penyusunan Bahan Ajar Kimia Inovatif Materi Laju Reaksi Terintegrasi Pendidikan Karakter Siswa SMA",Jurnal Tabularasa. 12(1), pp. 78-88, 2015.

[5]. M. Situmorang, M. Sinaga, D. A. Tarigan, C. J. Sitorus, A. M. L. Tobing,"The Affectivity of Innovated Chemistry Learning Methods to Increase Student's Achievement in Teaching of Solubility and Solubility Product", Jurnal Penelitian Bidang Pendidikan. 17(1), pp. 29-37, 2011.

[6]. M. Situmorang, M. Sinaga, J. Purba, S. I. Daulay M. Simorangkir, M. Sitorus, A. Sudrajat, "Implementation of Innovative Chemistry Learning Material With Guided Tasks to Improve Students' Competence", Journal of Baltic Science Education. 17(4), pp.535-550, 2018.

[7]. M. Situmorang, C. J. Sitorus, "The Innovation of Demonstration Method to Increase Student's Achievement in The Teaching of Solubility Product”,Jurnal Penelitian Bidang Pendidikan.8(1), pp. 1-7, 2012.

[8]. J. L. Badge, E. Dawson, A. J. Cann, J. Scott, "Assessing the Accessibility of Online Learning", Innovations in Education and Teaching International.45(2), pp. 103-113, 2008.

[9]. L. Mahdjoubi, M. A. A. Rahman, "Effects of Multimedia Characteristic on Novice CAD Learner's Practice Performance", Architectural Engineering and Design Management.8, pp. 214-225, 2012.

[10]. E. Milkova, "Multimedia Application for Educational Purpose: Development of Algorithmic Thinking", Applied Computing and Informatics. 11, pp. 76-88, 2014..

[11]. B. Zhaparova, Z. Schavalieva, M. Kenenbaeva, A. Theulesova, Soltanbaeva, S. B. Janat, N. Baitlessova, "On Training Future Teachers For Use of Multimedia Training Tools", Global Media Journal.2(19), pp. $1-5,2016$.

[12]. M. Situmorang, M. Sitorus, Z. Situmorang, "Pengembangan Bahan Ajar Kimia SMA/MA Inovatif dan Interaktif Berbasis Multimedia", Prosiding Semirata 2015 bidang MIPA BKS-PTN Barat, Universitas Tanjungpura Pontianak. pp. 533-542, 2015.

[13]. B. G. Tasci, "Project Based Learning From Elementary School to Collage, Tool: Architecture", Procedia- Social and Behavioral Science. 186, pp. 770-775, 2015.
[14]. H. Turgut, "Prospective Science Teachers' Conceptualizations About Project Based Learning", International Journal of Instruction. 1(2), pp. 61-79, 2008.

[15]. J. K. Robinson, "Project-Based Learning: Improving Student Engagement and Performance in the Laboratory", Analytical and Bioanalytical Chemistry Journal. 405(1), pp. 7-13, 2013.

[16]. A. Asan, Z. Haliloglu, "Implementing Project Based Learning In Computer Classroom", The Turkish Online Journal of Educational Technology.4(3), pp. 68-81, 2005.

[17]. M. Situmorang, "Kimia Analitik I (Kimia Analitik Dasar)", Fakultas Matematika dan Ilmu Pengetahuan Alam Universitas Negeri Medan, Medan, 2012.

[18]. C. C. Jacob, G. Dervilly-Pinel, G. Biancotto, B. Le Bizec, "Evaluation of Specific Gravity as Normalization Strategy For Cattle Urinary Metabolomics Analysis", Metabolomics.10, pp. 627-637, 2014.

[19]. S. Zhang, X. Zhang, "Teaching Analytical Chemistry in China: Past, Present, and Future Perspectives", Analytic and Bioanalytic Chemistry. 406, pp. 4005-4008, 2014.

[20]. D. C. Harris, "Quantitative Chemical Analysis, 9th ed.", W.H. Freeman and Company. New York, 2015.

[21]. D. A. Skoog, D. M. West, F. J. Holler, S. R. Crouch. "Fundamentals of Analytical Chemistry, 9th ed.", International ed. Brooks/Cole, Cengage Learning. Boston, 2013.

[22]. G. D. Christian, P. S. Dasgupta, K. Schug, "Analytical Chemistry, $7^{\text {th }}$ ed.", John Wiley \& Sons. New Jersey, 2013.

[23]. J. Purba, M. Situmorang, "Inovasi Pembelajaran Berbasis Proyek Untuk Meningkatkan Kompetensi Mahasiswa Pada Pengajaran Gugus Fungsi (Innovation of Project Based Learning to Improve Students Competecies on the Teaching of Functional Group)",Prosiding Seminar Nasional dan Rapat Tahunan BKS PTN-B bidang MIPA in Universitas Tanjungpura Pontianak, 6-9 Mei 2015 pp. 506-513, 2015.

[24]. J. Purba, M. Situmorang, "Inovasi Pembelajaran Berbasis Proyek Untuk Pengajaran Senyawa Enolat Pada Mata Kuliah Kimia Organik Lanjut", Prosiding Seminar Nasional dan Rapat Tahunan BKS PTN-B Bidang $M I P A$ in Graha Sriwijaya, Kampus UNSRI Bukit Besar Palembang, 22 24 Mei 2016.

[25]. M. Situmorang, M. Sinaga, M. Sitorus, A. Sudrajat,"Inovasi Bahan Ajar Interaktif Berbasis Multimedia Untuk Meningkatkan Kompetensi Mahasiswa Pada Pengajaran Kimia Analitik Dasar", Prosiding Seminar Nasional dan Rapat Tahunan BKS PTN-B Bidang MIPA in Jambi, 12 - 14 Mei 2017.

[26]. J. Purba, M. Situmorang, R. E. Dibiyantini,"Pengembangan Bahan Ajar Inovatif Berbasis Proyek Dengan Multimedia Untuk Meningkatkan Kompetensi Mahasiswa Pada Pengajaran Aldehida Dan Keton",Prosiding Seminar Nasional dan Rapat Tahunan BKS PTN-B Bidang MIPA in Jambi, 12 - 14 Mei 2017.

[27]. M. Sinaga, K. Sihombing K, M. Situmorang, "Inovasi Pembelajaran Interaktif Berbasis Kontekstual Untuk Meningkatkan Hasil Belajar Mahasiswa Pada Pengajaran Kimia Umum", Prosiding Seminar Nasional dan Rapat Tahunan BKS PTN-B Bidang MIPA in Jambi, Tgl 12 - 14 Mei 2017.

[28]. N. R. Marpaung, M. Situmorang, Pengembangan Bahan Ajar Kimia Inovatif Berbasis Pendekatan Saintifik Untuk Pengajaran Titrasi Asam Basa", Prosiding Seminar Nasional dan Rapat Tahunan BKS PTN-B Bidang MIPA in Jambi, 12 - 14 Mei 2017.

[29]. R. Siagian, M. Situmorang, "Pengembangan Bahan Ajar Inovatif Berbasis Saintifik Untuk Meningkatkan Hasil Belajar Mahasiswa Dalam Pengajaran Analisis Kation", Prosiding Seminar Nasional dan Rapat Tahunan BKS PTN-B Bidang MIPA in Jambi, 12 - 14 Mei 2017. 